$\mathbf{R}_{\text {ESEA }}^{\text {RCH }}$ RICLE

Members of the Research Forum

Associate Author :

${ }^{1}$ Department of Veterinary

Gynaecology and Obstetrics,

Vanbandhu College of Veterinary

Science and Animal Husbandry,

Navsari Agricultural University,

NAVSARI (GUJRAT) INDIA

${ }^{2}$ Livestock Research Station (NAU)

NAVSARI (GUJRAT) INDIA

${ }^{3}$ Department of Physiology and Biochemisty, Vanbandhu College of Veterinary Science and Animal Husbundry, Navsari Agricultural University, NAVSARI (GUJRAT) INDIA

AUTHOR FOR CORRESPONDENCE : D.K. SONI

Department of Veterinary Gynaecology and Obstetrics, Vanbandhu College of Veterinary Science and Animal Husbundry, Navsari Agricultural University, NAVSARI (GUJRAT) INDIA

\section{Reproductive performance and progesterone profile in post-partum acyclic surti buffaloes}

\author{
D.K. SONI, C.T. KHASATIYA ${ }^{1}$, A.S. REDE ${ }^{1}$, M.D. PATEL ${ }^{2}$ AND S.S. \\ CHAUDHARY ${ }^{3}$
}

\begin{abstract}
Postpartum acyclic surti buffaloes of an organized farm confirmed by twice perrectal palpation 11 days apart from 45 days postpartum were treated with $5 \mathrm{ml}$ of inj. Buserelin acetate I/M route in first group $(\mathrm{n}=6)$ and $5 \mathrm{ml}$ of inj. Buserelin acetate $\mathrm{I} / \mathrm{M}$ route along with $5 \mathrm{ml}$ inj. Vit. $\mathrm{AD}_{3} \mathrm{E}$ preparation and $15 \mathrm{ml}$ inj. Toldimphos sodium preparation $\mathrm{I} / \mathrm{M}$ route in second group ( $\mathrm{n}=6$ ) on 55 days postpartum after confirmation of acyclicity. Keeping 6 animals of same status as control to see the oestrus induction response and conception rate including weekly evaluation of blood progesterone profile, just before ( 0 day) treatment and 3 weeks after treatment ( $7^{\text {th }}, 14^{\text {th }}$ and $21^{\text {st }}$ day's post-treatment). The service period and oestrus induction interval in days was found significantly lower $(\mathrm{p}<0.05)$ in $\mathrm{GnRH}$ treated $\mathrm{T}_{1}(71.17 \pm 4.42 ; 12.67 \pm 1.11$ days $)$ and $\mathrm{T}_{2}\left(70.83 \pm 3.80 ; 12.33 \pm 1.11\right.$ days) groups as compared to control $\mathrm{T}_{3}(94.50 \pm 5.43 ; 30.75 \pm 3.95$ days) group under the study. It was observed that service period in the GnRH treated $\left(\mathrm{T}_{1}\right.$ and $\mathrm{T}_{2}$ ) groups has been minimized up to 23 to 24 days i.e. one cycle earlier in treatment groups than that of $\mathrm{T}_{3}$ control group. However, the number of services per conception did not differ significantly among all the experimental anoestrous treatment and control groups. Moreover, cent per cent conception rate in $\mathrm{T}_{1}(\mathrm{GnRH}$ alone $)$ and $\mathrm{T}_{2}(\mathrm{GnRH}+\mathrm{Vit} .+\mathrm{P})$ groups as compared to 66.66 per cent conception rate in acyclic control group $\left(\mathrm{T}_{3}\right)$, respectively might be under the influence of various treatments during period ( 45 to 120 days) with overall 88.89 per cent (16/18) conception rate. GnRH treatment instituted $\left(\mathrm{T}_{1}\right.$ and $\left.\mathrm{T}_{2}\right)$ groups revealed the increasing trend in progesterone concentration from $14^{\text {th }}$ and $21^{\text {st }}$ days post-treatment were increasing trend in progesterone concentration as $(0.93 \pm 0.26$ to $2.77 \pm 0.26 \mathrm{ng} / \mathrm{ml}$ and $1.39 \pm 0.30$ to $3.16 \pm 0.30 \mathrm{ng} / \mathrm{ml})$, respectively as compared to control $\left(\mathrm{T}_{3}\right)$ group. This might be due to use of GnRH treatment in that groups of animals postpartum leading to early resumption of ovarian follicular activity followed by conception. On the other hand, in control $\left(\mathrm{T}_{3}\right)$ group fluctuating trend $(0.41 \pm 0.06$ to $0.85 \pm 0.06 \mathrm{ng} / \mathrm{ml})$ in progesterone concentration at different time ( 0 day, $7^{\text {th }}$ day, $14^{\text {th }}$ day and $21^{\text {st }}$ day) intervals was found, that could be attributed to because of late settling (after 20 days with normal saline and rectal palpation) of pregnancy in that group.
\end{abstract}

Key words : Acyclic surti buffaloes, Hormone therapy, Progesterone, Postpartum period

How to cite this paper : Soni, D.K., Khasatiya, C.T., Rede, A.S., Patel, M.D. and Chaudhary, S.S. (2015). Reproductive performance and progesterone profile in post-partum acyclic surti buffaloes. Vet. Sci. Res. J., 6(2) : 94-99.

Paper History : Received : 08.06.2015; Revised : 22.08.2015; Accepted : 26.09.2015 